„Bohemistyka” 2020, nr 3, ISSN 1642-9893

Przemysław ZNOJEK

DOI: $10.14746 /$ bo.2020.3.7

Uniwersytet Jana Kochanowskiego

\section{Wizerunek Romów w prozie Bohumila Hrabala}

Keywords: Bohumil Hrabal, Romanies, literature, Czech prose of the $20^{\text {th }}$ century, history

Słowa kluczowe: Bohumil Hrabal, Romowie, literatura, proza czeska XX wieku, historia

\section{Abstract}

The purpose of this article is to show the stereotypical perception of the Romany minority inhabiting Prague the capital of Czechoslovakia in the 1960s and 1970s. Hrabal presented the image of Romany on the cards. The most visible in Romanca's works (in the 1964 Pábitelé collection) and Too Loud a Solitude (Př́liš hlučná samota from 1976). As part of the implementation of the paper, a detailed analysis of literary material will be carried out, as well as cultural and historical reflection. My idea is to try to present the fate of the Romany community, which was close to the Czech writer.

Celem niniejszego artykułu jest ukazanie stereotypowego postrzegania mniejszości romskiej zamieszkującej Pragę, stolicę Czechosłowacji w latach sześćdziesiątych i siedemdziesiątych XX wieku. Wizerunek Romów prezentował na kartach swych opowiadań Bohumil Hrabal. Najbardziej widoczny jest w utworach Romanca (znajdującej się w zbiorze Pábitelé z 1964 roku) oraz Zbyt głośna samotność (Př́lišs hlučná samota z 1976 roku). W ramach realizacji referatu przeprowadzona zostanie szczegółowa analiza materiału literackiego, jak również refleksja kulturoznawcza i historyczna. Moim zamysłem jest próba przedstawienia losów społeczności romskiej, która bliska była czeskiemu pisarzowi.

Bohumil Hrabal bohaterami literackimi swojej prozy czynił przede wszystkim postacie $\mathrm{z}$ krwi i kości, wywodzące się często z nizin społeczeństwa, żyjące na marginesie, outsiderów. Dla pisarza urodzonego nad Wełtawą najważniejszy był realistyczny przekaz literacki, stąd zamiłowanie autora do wybierania na pierwszoplanowe postaci kelnerów, pakowaczy makulatury, artystów amatorów czy pomocników hydraulików. Wynikało to z charakterystycznego dla Hrabala podejścia do literatury, które miało przypominać rodzaj oralnej opowieści. Wprowadzał typy oratorów z gospody, niezmordowanych opowiadaczy życiowych historyjek przy kuflu piwa. Zdaniem Zofii Tarajło-Lipowskiej,

Budulcem wielu utworów Hrabala jest gatunek zwany: hospodská historka (historyjka z szynku, z karczmy), oparta na fabule stylizowanej na fakt. Bliski gawędzie, pozorne exemplum (pozorne ze względu na częsty antydydaktyzm i rozbijanie stereotypów), o bardzo otwartej i produktywnej formie [...] Inna nazwa tego gatunku to kec lub pábení (stąd: pábitelé), choć określenie to nie uwypukla nacisku na generowanie tekstu w środowisku hospody, podkreśla raczej profuzję słowa i hiperbolizację treści (Tarajło-Lipowska 2010, s. 366).

Twórczość pisarza urodzonego w Brnie cechowała autobiograficzność. Hrabal zręcznie wplatał w literacką fabułę wątki i sylwetki osób, które spotkał na krętej drodze swojego życia. Był bowiem wytrawnym obserwatorem otaczającej go rzeczywistości, potrafił idealnie uchwycić trudne i często przemilczane kwestie dotyczące życia w komunistycznej Czechosłowacji. Warsztat literacki Hrabala charakteryzował się połączeniem realizmu i naturalizmu. Autor niewatpliwe czerpał wzorce z psychoanalizy, próbował przedstawić za pomocą formy artystycznej stan psychiczny oraz emocje, którymi kierowali się jego bohaterowie. Nie obce były mu wątki historyczne skrzętnie wplecione w fabułę utworów, stąd najczęściej prezentował życie jednostki w niesprzyjającej rzeczywistości dziejowej np. II wojny światowej czy ustroju komunistycznym. Posługiwał sie przy tym właściwa dla swojego pisarstwa liryzacją prozy, wzbogacając ją licznymi metaforami. Nadawał mu refleksyjny kierunek. Dorobek literacki pisarza nosił wszelkie znamiona typowe dla twórczości rozumianej z perspektywy aergocentrycznej.

W swojej prozie pisarz wielokrotnie prezentował jednostki wywodzące się ze społeczności romskiej. Nie bez znaczenia był fakt, że Hrabal miał okazję obserwacji życia Romów w czasie zamieszkiwania robotniczej nieco zaniedbanej dzielnicy Pragi - Libeň, gdzie wiódł spokojne życie w mieszkaniu przy ulicy na Hrázi (na Grobli) 24 (Engelking 2015,s. 109). W tym czasie miał liczne okazje do przygląda- 
nia się swoim sąsiadom, którzy byli Romami. Autor po latach wspominał:

Tu, na Libni, podobało mi się najbardziej, tu mieszkałem dwadzieścia lat z Cyganami, aktorami, pijakami, uprzejmymi kobietami, wszyscy oni jakoś tak mnie lubili, wszyscy zwracali się do mnie czule: Bohoušku - jak w Židenicach. Krąg moich miejsc zamieszkania i wędrówek, i poszukiwań zamknął się tam, gdzie się rozpoczął, wszystko inne były to tylko lata terminowania, uniwersytet, podczas gdy Židenice i Liben̆ - to było moje prawdziwe życie (Kaczorowski 2016, s. 75).

Libeň zamieszkiwali przede wszystkim pracownicy fizyczni, robotnicy czy pakowacze makulatury. Sam autor w latach 60. XX wieku poza pisaniem parał się pracą fizyczną, żeby zarobić na życie. Pracował między innymi w teatrze, zajmując się rozstawianiem dekoracji, czy w skupie makulatury, sortując prasę oraz książki. Dzielnica Pragi, w której przyszło mieszkać pisarzowi od lat 50. XX wieku stanowiła dla niego główne miejsce obserwacji, a zarazem literackich inspiracji. Atmosfera libeńskich przedmieści, a przede wszystkim jej mieszkańcy zostali sportretowani w opowiadaniach m.in. w Barze Świat (Automat Svět).

W utworach prozatorskich Hrabala pojawiały się postacie pochodzenia romskiego. Analizując spuściznę literacką pisarza, zauważyłem zainteresowanie Romami, których przeważnie umieszczał w swojej prozie jako bohaterów pobocznych, często drugo- bądź nawet trzecioplanowych, konsekwentnie określał ich mianem Cyganów. W komunistycznej Czechosłowacji było to powszechne określenie, niosące za sobą niejednoznaczne nacechowanie. Używane było w różnych kontekstach, zarówno pejoratywnych, jak i pozytywnych.

\section{Romowie w Czechoslowacji}

Romowie jako mniejszość narodowa Czechosłowacji wymykali się jednoznacznym klasyfikacjom. Kwestię sporną stanowiło choćby popularne określenie etniczne - Cyganie, które współcześnie uznawane jest za pejoratywne. Trzeba tu dodać, że nie wszystkie grupy romskie uznają określenie Cyganie za negatywne, część z nich nazywa siebie Cyganami czy po prostu Wędrowcami (Travellers), część zaś Romami. Największe skupiska romskie znajdują się na Półwyspie Bałkańskim, a także w Europie Środkowej i Zachodniej. Najtragiczniejszym rozdziałem w historii Romów była bez wątpienia II wojna światowa i związana z nią eksterminacją ludności, określana przez badaczy jako ,zapomniany Holocaust”. Według niektórych źródeł na terenie Protektoratu Czech i Moraw w latach 1939-1945 zginęło około 6,5 tysiąca Romów. Jerzy Ficowski stwierdził:

Osławione Ustawy Norymberskie stojące na straży czystości krwi niemieckiej, klasyfikowały Cyganów - obok Żydów i Murzynów - jako element zagrażający czystości rasy (Ficowski 1953, s. 95).

Po wojnie nastapiła migracja społeczności romskiej z terenów słowackich do czeskich miast. Komunistyczna polityka Czechosłowacji dążyła do homogenizacji narodu czeskiego, który miał prowadzić do utworzenia państwa jednolitego kulturowo i etnicznie, marginalizowała kwestię Romów. Zdaniem Macieja Witkowskiego.

Dla rządów partii komunistycznej Romowie jako grupa zasadniczo odmienna kulturowo, stanowili problem zarówno z praktycznego, jak i ideologicznego punktu widzenia. Romowie byli bowiem z jednej strony społecznością o bardzo niskim statusie społecznym, ich współżycie z resztą społeczeństwa było źródłem wielu konfliktów, a z drugiej, stanowili grupę etniczną oczekującą uznania własnych praw i niepoddającą się normom socjalistycznego społeczeństwa, zwłaszcza jeśli chodzi o zatrudnienie, zamieszkanie czy edukację (Witkowski 2003, s. 107-108).

W latach 50. XX wieku komunistyczne władze Czechosłowacji postanowiły narzucić społeczności romskiej przymusową asymilację z pozostałą częścią społeczeństwa. Wszystkich Romów przebywających na terenie Czechosłowacji zakwaterowano w blokach, nakazano im znalezienie stałej pracy zarobkowej czy nałożono obowiązek uczęszczania do szkół romskich dzieci. Narzucona integracja Romów nie przyniosła oczekiwanych efektów, dlatego w latach 60. XX wieku zdecydowano sie na wprowadzenie nowej polityki, której głównym celem miała być adaptacja społeczna Romów. Przeprowadzona została w sposób mniej rygorystyczny, co wynikało przede wszystkim z sytuacji politycznej i nastrojów społecznych w Czechosłowacji. 
Trend wolnościowy, który towarzyszył czeskiej i słowackiej zbiorowości do 1968 roku został brutalnie stłumiony w wyniku interwencji zbrojnej wojsk Układu Warszawskiego.

W latach 70. XX wieku w czasie tak zwanej normalizacji władza ponownie skłoniła się ku rygorystycznej polityce państwa w stosunku do mniejszości romskiej, polegającej na przymusowej asymilacji oraz wprowadzeniu znanego już z lat 50. XX zakazu koczownictwa i włóczęgostwa, jak również kategorycznego zakazu używania języka romskiego w szkołach. Przedstawiciele rządu przygotowali program osiedlania Romów, który zaczęli wprowadzać w życie. Polegał on na przekazywaniu im na własność mieszkań, co wzbudziło niemałe kontrowersje wśród większości społeczeństwa ówczesnej Czechosłowacji. Pomysł spotkał się również z dezaprobatą ze strony samych Romów, którzy nie potrafili odnaleźć się w nowej sytuacji prowadzenia ustabilizowanego życia. Program stał się powodem narastania licznych napięć między narodem czeskim a mniejszością romska, tym bardziej że na lata 70. przypadał deficyt na rynku mieszkaniowym. Cyganie po otrzymaniu lokali mieszkalnych na własność często doprowadzali je do ruiny. Nie potrafili odpowiednio zadbać o nie, zalegali z opłatami, bytowali w jednym mieszkaniu w kilkanaście osób lub po prostu opuszczali je, kierując się koczowniczą naturą. Działania komunistycznej władzy doprowadziły do ożywienia uprzedzeń rasowych oraz narastania ogólnospołecznej niechęci do Romów. Opór społeczny i niezrozumienie rodziła, poza tym tradycyjna kultura romska, a w szczególności zawieranie małżeństw przez mniejszość romską w bardzo młodym wieku. Zgodnie z tradycją, już nastolatkowie, jeśli tylko osiągnęli dojrzałość fizyczną, mogli wejść w związek małżeński, dlatego też reguła było (i jest nadal), że nastoletnie dziewczęta wychodziły za mąż i rodziły dzieci. Śluby takie według prawa cygańskiego nie musiały być zawierane oficjalnie w urzędach państwowych czy kościołach, najważniejsze, żeby były zgodne z tradycyjnym obrządkiem romskim. Takie postępowanie prowadziło do powstawania problemów o charakterze socjalnym.
Barierą utrudniającą asymilację Romów w Czechosłowacji był także język, który zaliczany był do syntagmy wewnętrznej, etnicznej kultury. Dialekt romski odgrywa ogromną rolę w kulturze cygańskiej i należy do symboli rozpoznawczych grup romskich, które posługują się nim na całym świecie. Romowie zamieszkujący Czechosłowację pielęgnowali swoją tradycję językową przez posługiwanie się w codziennej komunikacji jedynie językiem romskim. Ortodoksyjni Romowie wykazywali sprzeciw wobec nauki języka czeskiego, dążąc do funkcjonowania hermetycznych grup na terenie Czechosłowacji. Mniej restrykcyjni podejmowali próby porozumiewania się w języku czeskim, jednak tylko w mowie.

Kolejnym z czynników utrudniającym nawiązanie relacji między Romami a Czechami była przestępczość, kradzieże oraz żebractwo, którego dopuszczały się grupy romskie. Patologiczne zachowania niosące za sobą pierwiastek kryminogenny nie są oczywiście akceptowane w żadnym społeczeństwie, jednak Romowie posiadają inną koncepcję własności prywatnej oraz jej poszanowanie. Zdaniem Anny Lubeckiej

Kodeks postępowania romskiego dopuszcza oszukanie „gadzia”, wykorzystanie go i jego własności dla celów własnych [...] takie postępowanie nie jest niegodziwe i niemoralne, przeciwnie, spotyka się z aprobata współziomków (Lubecka 2005 , s. 63).

Największy problem wśród społeczności romskiej stanowiły liczne kradzieże. Sporną kwestię powodowała także przestępczość wśród romskich dzieci i młodzieży. Należy wymienić w tym miejscu zjawisko prostytucji, które umacniało negatywny wizerunek Romów w czeskim środowisku.

Źródła niechęci w stosunku do Romów miały charakter bardziej złożony i niejednorodny. Niewatpliwie kluczową rolę odgrywała w postrzeganiu grup romskich nie do końca rozumiana tradycja i kultura, która dla Czechów stanowiła pewne novum. Wpływ na taki stan rzeczy miały również negatywne zachowania Romów, w tym hałas czy nieporządek, który powodował napięcia pomiędzy społecznościami. W Czechosłowacji występowały różne przejawy niechęci i nietole- 
rancji wobec Romów. Działania i ataki motywowane ksenofobią czy rasizmem przyczyniały się do pogłębienia negatywnego wizerunku Romów, co miało prowadzić do ich postępującej marginalizacji. Najczęściej występującym przejawem dyskryminacji etnicznej było werbalizowanie negatywnych emocji w sposób kierowania obraźliwych słów w kierunku Romów. Najpopularniejszymi hasłami głoszonymi w stosunku do społeczności romskiej były: Cikáni do plynu, Černá svině czy Černé huby.

Forma dyskryminacji na tle etnicznym było przymusowe osiedlanie Romów w określonych miejscowościach bądź dzielnicach większych miast, co sprzyjało gettoizacji oraz segregacji rasowej mieszkańców. Efektem tego była silna izolacja i marginalizacja zbiorowości romskiej oraz powstawanie $\mathrm{w}$ miastach enklaw o różnym poziomie życia. Najbardziej znanym przykładem romskiego getta było powstałe w latach 70. XX wieku osiedle Chánov w mieście Most. W kilku blokach podobnych do slumsów żyło ponad półtora tysiąca Romów.

Mimo niejednokrotnych wyrazów niechęci wobec Romów, wytwory ich kultury cieszyły się zainteresowaniem Czechów i Słowaków. Podkreślano w nich walory wynikające przede wszystkim z ,inności” oraz oryginalności. Doceniano zawarte w ich folklorze elementy wolności, przejawiajace się m.in. w barwnych cygańskich strojach. Pojawiające się w miejscowościach czeskich tabory niekiedy wzbudzały poruszenie mieszkańców, którzy z ciekawością obserwowali przybyszów w ich codziennym życiu. Grzegorz Węgrzyn zauważa:

Kultura cygańska przetrwała przede wszystkim w pieśniach, ustnych przekazach, a także w prawie. Inspirowała ona wielu artystów nie-Cyganów, tworzących przy wykorzystaniu elementów cygańskiego folkloru muzykę, operę, przekazujących na płótnach barwy życia taboru. Cyganie pozostawili na terenach, gdzie żyli, wspaniałe dzieła kowalskiego rzemiosła, ozdoby, dzwony, a także kolorową baśń, przekazywaną z pokolenia na pokolenie (Węgrzyn 1992, s. 94).

Społeczność romska rozsiana była w zasadzie po większości czeskich miast. Najczęściej wybierali miasta większe, przemysłowe, co było skutkiem polityki komunistycznej. Zajmowali mieszkania po wysiedlonych Niemcach. Największe skupiska ludności romskiej występowały w takich czeskich miastach jak: Praga, Brno, Ołomuniec czy Ostrawa. Najliczniejszą grupę zbiorowości romskiej w Czechach tworzyli Romowie słowaccy (Servika Roma, Romové slovenšti), kolejną Romowie węgierscy (Ungrika Roma, mad'arští Romové) oraz Romowie wołoscy (Vlachike Roma, Olaššti Romové).

\section{Romscy bohaterowie utworów Hrabala}

W prozie Bohumila Hrabala postacie pochodzenia romskiego występowały w różnych wątkach. Romowie, których na kartach swych opowiadań określał Cyganami, pojawiali się między innymi w Pięknej rupieciarni, Listach do Kwiecieńki czy Obstugiwałem angielskiego króla. Opisywani byli w sposób niejednorodny, raz z nacechowaniem negatywnym, jak w przypadku Obstugiwałem angielskiego króla (Cygan, jako drobny rzezimieszek, pojawiający się na ulicy z nożem, szukający zatargu), czy zdecydowanie bardziej pozytywnym (Cyganie, jako naród wyzwolony, pociągający w tym wyzwoleniu), jak w Listach do Kwiecieńki. Motyw romski najbardziej widoczny był jednak w opowiadaniu Romanca, zawartym w zbiorze Pabitele (wydanym w 1964 roku). W utworze tym pisarz prezentował historię znajomości, która przerodziła się w romans między Czechem a Cyganką. Gaston Koszulka (nazwisko w tłumaczeniu na język polski) był młodym mężczyzną, przeciętnym i zakompleksionym, żyjącym w rzeczywistości szarej, komunistycznej Czechosłowacji. Jedyną rozrywką pomocnika hydraulika były wizyty w kinie, szczególnie gdy na wielkim ekranie pojawiały się filmy z gatunku ,płaszcza i szpady”. Po jednym z seansów, pod kinem spotkał młodą i piękną Cygankę, która zwróciła jego uwagę nietypową sukienką (dwa fartuchy spięte agrafkami). Kobieta zauważyła zainteresowanie ze strony Gastona, postanowiła wykorzystać okazję i poprosić go najpierw o papierosa, a później o pieniądze na wyróżniający się na sklepowej wystawie różowy sweter. Młody mężczyzna zgodził się na propozycję Cyganki, a ta za- 
prowadziła go do miejsca swojego pobytu. Hrabal zwracał uwagę na opis budynku, w którym mieszkała Małgorzata.

A ulička byla tichá a rozbitá a slibovala, že se v ní může ledacos přihodit, ledacos stát. Vysoká plynová lucerna stála před rozbitým stavením, které se podobalo tyrolskému statku. Do prvního patra mizely dřevěné schody. Zřetelně zábradlí se na jedné stráně zř́tilo a viselo šikmo jak žebř́k [...] Když se vyškrábal nahoru, viděl, že do střechy je díra s jsou vidět hvězdy (Romance; Hrabal 2014, s. 236).

Pisarz posługując się realistycznym opisem, podkreślał problem doprowadzania do ruiny mieszkań, które Romowie dostawali na własność zgodnie z komunistycznym programem asymilacyjnym. Budynek prawdopodobnie należał w przeszłości do wysiedlonych mieszkańców Czechosłowacji o pochodzeniu niemieckim bądź austriackim. Z jednej strony autor podkreśla zaniedbany stan obiektu mieszkalnego, $\mathrm{z}$ drugiej zaś pisał:

A v jednom ze dvou oken záŕila plynová lucerna, která vyrostla $\mathrm{z}$ chodníku a šikmo svítila na podlahu velkého, prázdného pokoje, a světlo lucerny se lomilo o zrcadlo, které leželo na futře okna a házelo na strop stř́brný obdélník, z kterého se do pokoje sypalo a mžilo jemné a něžné světlo, které rozehrávalo všecka sklička benátského lustru, který visel od stropu a třpytil se jak klenotnický krám. A strop pokoje byl klenutý a s kvelbem jak rozevřený bílý deštník o čtyřech drátech (Romance; Hrabal 2014, s. 237)

Nieprzypadkowo prozaik użył kontrastu, jakim bez wątpienia był luksusowy żyrandol w pustym i ubogim mieszkaniu. Ukazał jedna z cech, którymi wyróżniali się Romowie, mianowicie zamiłowanie do rzucających się w oczy bibelotów na pozór niepotrzebnych. Wystawny żyrandol może być odczytywany także jako symbol pędu do bogacenia się Romów, którzy niejednokrotnie podejmowali się intratnych zajęć, często niezgodnych z obowiązujacym prawem, po to tylko, żeby zdobyć kosztowną rzecz, którą mogliby pochwalić się wśród współziomków.

Hrabal w opowiadaniu utrzymywał także inny stereotyp dotyczacy społeczności romskiej, mianowicie, że zajmowali się oni przeważnie praca fizyczna, która podejmowali między innymi w praskich fabrykach. Główna bohaterka prozy była pracownicą cegielni, w której zaj- mowała się prostymi zajęciami, sprzątała i gotowała dla robotników. Brak odpowiedniego wykształcenia wynikajacy z kultywowania tradycji romskiej nie pozwalał na podejmowanie przez Romów bardziej odpowiedzialnych i lepiej płatnych stanowisk pracy. Przyczyna, która mogła stygmatyzować społeczność romską i przypisywać ją tylko do wykonywania prac fizycznych, wynikała z komunistycznej propagandy przedstawiającej tę mniejszość w sposób negatywny.

Autor prezentował również utarty w świadomości stereotyp młodych romskich kobiet, które z chęci zysku oddawały się mężczyznom za pieniądze. Bohaterka Romancy zdecydowała się na współżycie $\mathrm{z}$ nieznajomym Czechem za pięćdziesiąt koron, czyli cenę wymarzonego swetra znajdującego się po drugiej stronie sklepowej witryny. Priorytetem decydującym o zainteresowaniu Gastonem był fakt, że posiadał przy sobie określona sumę gotówki. Po tym jak młody mężczyzna zabrał Cygankę do swojego mieszkania, kobieta pozytywnie zaskoczona warunkami bytowymi, zaczęła snuć wspólne plany na przyszłość:

Začneme spolu žít na hromádce, a když se ti to nebude líbit, tak mé můžeš vyhnat Ale až pak. Já umím vařit, uklízet, vyprala bych ti, zašila, donesla oběd. A rozeplá bych se ti celá (Romance, Hrabal 2014, s. 240).

Słowa młodej kobiety wyraźnie podkreślają tradycyjny układ patriarchalny mający miejsce w społeczności romskiej. Cyganki narażone były na marginalizacje, w kulturze romskiej miały być przede wszystkim odpowiedzialne za dom i dzieci, rola mężczyzny była niepodważalna. Stąd niechlubne przypadki, kiedy Romowie stawali się sutenerami wobec najbliższych im kobiet.

Młoda Cyganka przyznała się również Gastonowi, że ma już córkę $\mathrm{z}$ innym przedstawicielem narodu czeskiego. Nie widziała $\mathrm{w}$ tym jednak nic zdrożnego, uznając, że w jej kulturze było to normalne. Co ciekawe, snując plany na przyszłość u boku młodego Czecha, brała pod uwagę, że jej córka z nimi zamieszka:

Tak jako jsem spávala já. Bude spát v šupleti od kanape nebo v almaře. A potom, Margitce už budou tři roky a dojde ti pro cigarety, pro pivo, podá ti bačkory (Romance; Hrabal 2014, s. 240). 
Kobieta uprzedmiotawia rolę córki do służącej, która w przyszłości miałaby być usłużna wobec mężczyzny. W jej przekonaniu dominował tradycyjny ustrój patriarchalny, który był typowy dla romskiej społeczności. Kobieta nie dostrzega marginalizowania jej roli, co więcej przyznaje, że w dzieciństwie również była traktowana $w$ ten sposób przez rodzinę. Zdaje się nie zauważać zagrożeń płynących z wychowania dziecka w podobnych warunkach.

Hrabal w opowiadaniu nie szczędził od opisów wyglądu zewnętrznego przedstawicieli społeczności romskiej. Wprowadzał czytelnika w praskie zakątki miasta, w których przebywali Cyganie. Podkreślał ich odrębność, niezależność, a zarazem zainteresowanie, jakie wzbudzali wśród reszty społeczeństwa. Pisał:

Tam na náplavce ležel v peřinách obrovský nahatý cikán, ležel naznak a celý trup byl venku a jak leporelo byl poset vytetovanými obrázky. Jednu ruku měl založenou pod hlavou a měl takový sval, že to maso dělalo podušku. Dva kníry se podobaly koňským ocasům. A ten obr volnou rukou klidně kouřil, díval se do modrounkého nebe na poslední hvězdu a kouřil. Vedle něj spočívala chundelatá hlava s obličejem v polštáŕi. A zpod mostního oblouku trčela voj od bryčky s plachetkou a zadek hnědého koně, který mrskal ocasem sem a tam (Romance; Hrabal 2014, s. 242-243).

Pisarz zaprezentował także jeden z tradycyjnych zwyczajów romskich polegający na tym, że gdy przychodziły dni wiosenne oraz letnie chętnie opuszczali oni swoje mieszkania i spali na otwartej przestrzeni. Sen pod gołym niebem miał przede wszystkim ukazywać zamiłowanie do wolności, nieskrępowanej natury, ale także przyrody. Stanowił symbol niezależności społeczności romskiej. Autor zaznaczał:

A tam dole se nořila z modrého oparu Praha, elektrické žárovky ještě svítily a ověšovaly město girlandami světel jak cirkus, který zapomněli zhasnout. Petřínská věž ještě záŕila červenými varovnými signály a na hromosvodu střešovického komínu svítil rubín, ale tady spali cihlářští dělníci, na které se sypal odkvetlý akát... Cikáni, bývalí nomádi, kteří nedávno přijeli na koleskách a bryčkách do Prahy s náušnicemi a mysliveckými kloboučky, aby vyměnili romantické harcování za obyčejnou práci (Romance; Hrabal 2014, s. 245).
Romanca była utworem poświęconym społeczności romskiej, którą pisarz obserwował przez pryzmat rodowitego Czecha pracującego z Romami, mieszkającego w ich sąsiedztwie czy spotykającego ich na praskich ulicach. Realistyczny obraz postanowił uwiecznić na kartach opowiadania, nie pomijając wszechobecnych stereotypów, ale również nie wartościując czy umoralniajac. Ostatecznie osiemnastoletnia Cyganka miała pozytywny wpływ na życie Gastona, dzięki niej stał się dojrzałym i pewnym siebie mężczyzną. Zakończenie utworu pozostawia czytelnika z nieodpartym wrażeniem, że młody Czech darzył Małgorzatę prawdziwym uczuciem, dla którego był w stanie sprzeciwić się własnej matce, która miała utarte przekonania na temat tej mniejszości narodowej.

Kolejnym przykładem, tym razem powieści, w której pojawiała się postać wywodząca się ze społeczności romskiej, była Zbyt głośna samotność. Pisarz ukończył tekst w lipcu 1976 roku, a popularność zyskała w obiegu niezależnym. Stała się jednym z najbardziej rozpoznawalnych dzieł autora. Maciej Robert pisał:

Zbyt głośna samotność to liryczna parabola o literaturze, która staje się makulaturą i z makulatury powstaje na nowo, o łatwości zjaką skazuje się ludzi i ich dzieła na zapomnienie i o historii, która odradza się na śmietniku epoki. W powieści tej Hrabal ożywił mit Syzyfa i jego współczesne aktualizacje (obecne chociażby u francuskich egzystencjalistów) oraz zawarł mnóstwo odwołań historiozoficznych i literackich (Robert 2014, s. 43)

Główny bohater powieści - Haňta, charakterystyczny dla aergocentrycznej twórczości Hrabala, wzorowany był na osobie Jindřicha Peukerta, który pracował wspólnie z pisarzem przy sortowaniu starego papieru. Doświadczony przez życie mężczyzna, Czech, który „trzydzieści pięć lat prasuje stary papier”, był pracownikiem skupu makulatury. W czasie pracy odwiedzały go Cyganki, które zajmowały się zbieraniem makulatury, zarabiając przy tym na życie. Podobnie jak w Romance pisał o niesprawiedliwym podejściu Romów wobec kobiet. Mozolne zbieranie makulatury przez dwie Cyganki nadzorował mężczyzna, którego Hrabal nazywał ,alfonsem”, fotografował on ich pracę. 
W Zbyt głośnej samotności Hrabal prezentował stereotyp mniejszości romskiej, najczęściej zajmującej się pracą fizyczną. Wynikał on z braku wykształcenia wymienionej społeczności, która „obchodziła" obowiązek szkolny. Co prawda jej przedstawiciele w ramach obowiązującego prawa byli zmuszeni posyłać dzieci do placówek oświaty, jednak ze względu na koczowniczy tryb życia, nierozerwalnie związany z cygańską tradycją, nie pozwalało to na ciągłe kształcenie i powodowało problemy edukacyjne skutkujące brakiem możliwości podjęcia pracy umysłowej. Dzieci mniej ortodoksyjnych Romów, którzy zdecydowali się zrezygnować z wojaży, w wyniku utrudnionej asymilacji społecznej narażone były na niepowodzenia szkolne, które uniemożliwiały im uzyskanie promocji do programowo wyższej klasy. Wymieniona sytuacja niejednokrotnie powodowała, że zmuszone były pozostawać na tym samym poziomie edukacyjnym przez kilka lat, co w rezultacie prowadziło do usuwania ich ze szkół. Hrabal na kartach powieści zawarł godne uwagi spostrzeżenie, wynikające z obserwacji pracującego Cygana, który pełnił służbę na jednej z praskich ulic. Pisał on:

Tam U Schollerů v zatáčce, a tam řídil dopravu cikánský příslušník Veřejné bezpečnosti, měl bílé rukávy a proužkovanou hůl a otáčel se do uvolněných směrů dopravy tanečním polkovým krokem tak krásně a tak důstojně, že i já jsem se zastavil a díval jsem se na to, s jakou pýchou ten cikán koná svoji půlhodinku, než je vystř́ídán [...] A když potom nadešla chvíle a cikán si předal službu na křižovatce $\mathrm{s}$ jiným př́slušníkem Veřejné bezpečnosti, stál ted’ uprostřed svých cikánů a přijímal gratulace a pocty, a ty moje dvě cikánky najednou padly na kolena (Hrabal 2012, s. 44).

Pisarz prezentował fascynacje egzotyczną urodą przedstawicieli społeczności romskiej. Podkreślał naturalnie piękny wygląd młodych Cyganek, zwracał także uwagę na atrakcyjność mężczyzn romskich. Przede wszystkim ich wygląd zewnętrzny stanowił wyraźny kontrast $\mathrm{z}$ typową urodą słowiańską. Wizerunek Cyganów charakteryzujących się śniadą karnacją cery oraz ciemnym kolorem włosów, porozumiewających się w odmiennym języku, często ubranych w kolorowe, rzucające się w oczy ubrania wzbudzał powszechną ciekawość. Intry- gujący czynnik stanowiła swoista „inność” wyrażająca się przez ich urodę oraz ubiór, a co za tym idzie kulturę.

Hrabal na kartach utworu podkreślał zafascynowanie tradycyjną kulturą romską, pisząc, że

Mají tihle cikáni oči, tak veliké a tak moudře oči nějaké dávno zapomenuté kultury, slyšel jsem, že když my jsme ještě běhali se sekyrkami a přepásávali se kozí, tak cikáni někde měli stát a zřízení, které už zažilo druhý úpadek (Hrabal 2012, s. 49).

W przytoczonym fragmencie autor odwoływał się do historii zbiorowości romskiej, która miała wywodzić się od Radżputów, czyli przedstawicieli wojowniczych rodów zamieszkujących obszar Indii. Zostali oni zmuszeni do opuszczenia kraju i koczowniczego trybu życia przez brutalne najazdy muzułmanów z zachodu na Indie w X-XI wieku. $\mathrm{W}$ wyniku walk śmierć poniosło miliony Radżputów, nastąpił pierwszy upadek społeczności, z której swój początek mieli wziąć Cyganie. Kolejnym wydarzeniem, które miało prowadzić do schyłku, a co za tym idzie rozproszenia społeczności romskiej była wielka bitwa między muzułmanami i Radżputami w XII wieku, w czasie której przodkowie Cyganów doznali druzgocącej porażki. Przegrana w boju $\mathrm{z}$ muzułmanami oraz zagarnięcie przez nich obszaru zamieszkiwanego niegdyś przez Radżputów skutkowała drugim i zarazem ostatecznym ciosem zadanym w pierwszych Cyganów (Wegrzyn 1992, s. 80).

W powieści pojawiał się kolejny stereotyp dotyczący społeczności romskiej, czyli rozwiązłość kobiet wywodzących się z tego środowiska. Cyganki, które odwiedzają głównego bohatera namawiają go do współżycia, nie przeszkadza im nawet zaawansowany wiek mężczyzny. Zachowanie kobiet wywodzących się ze społeczności romskiej wydawało się kontrowersyjne. Wynikało ono z zasad współżycia, którymi kierowały się Cyganki ceniące sobie wyzwolenie seksualne. Wpływ na takie prowadzenie się mogła mieć najprawdopodobniej tradycja związana z zawieraniem małżeństw w bardzo młodym wieku. Niedojrzałe dziewczęta ponaglane do wyjścia za mąż, a w efekcie tego inicjacji seksualnej, miały zachwianą sferę intymności, dlatego stosunek płciowy z przypadkowym mężczyzną mogły traktować jako niewinny uczynek. Stawał się dla nich formą wyzwolenia od z reguły 
niekochanych mężów. Niekiedy zbliżenie łączyło się z desperacką próbą poszukiwania warunków lepszego życia, odcięcia się od rodziny czy miało charakter pracy zarobkowej.

W interesujący sposób Hrabal opisywał romans głównego bohatera z kobieta pochodzenia romskiego. Pod koniec II wojny światowej poznał on Cygankę na jednej z praskich ulic, wracając do swojego mieszkania po nocnej libacji. Kobieta odprowadziła go aż do samych drzwi czynszówki (Na Grobli - motyw autobiograficzny) i ku zdziwieniu mężczyzny postanowiła z nim zamieszkać. Kobieta najprawdopodobniej była samotna, możliwe, że straciła rodzinę w wyniku działań zbrojnych nazistów. Haňta stanowił dla niej pewnego rodzaju opokę. Znajomość z nim pozwalała jej odnaleźć element poczucia bezpieczeństwa, który w tragicznym czasie wojny wydawał się być bezcenny. Nie można wykluczyć hipotezy, że kierowała się także perspektywą poszukiwania lepszych warunków do życia, jednak należy zauważyć, że Cyganka prawdopodobnie darzyła mężczyznę uczuciem. Niecodzienna przygoda miłosna pozostawiła niezatarte ślady w przywoływanych wspomnieniach bohatera.

Cikánku, která nic víc nechtěla než topit $\mathrm{v}$ kamnech dřívím, které přinášela na zádech ty těžké tramy a prkna z bouraček, dřeva veliká jako kř́̌ž, nechtěla opravdu víc než vařit bramborový guláš $\mathrm{s}$ koňským salámem, přikládat do kamen a na podzim pouštět draka na nebesa (Hrabal 2012, s. 68).

Opisując historię relacji głównego bohatera z kobietą romskiego pochodzenia, autor zwracał uwage na dramatyczne losy Romów pod koniec II wojny światowej. Odwoływał się do „zapomnianego Holocaustu", którego ofiarami była wymieniona społeczność. W początkowo groteskową i irracjonalną opowiastkę wpisał elementy historyczne, podkreślające tragiczny wydźwięk rzeczywistości wojennej. Hrabal pisał, że

Až potom jsem se dozvěděl, že ji sebralo gestapo s ostatními cikány a odvezli ji do koncentráku, odkud už se nevrátila, spálili ji někde v Majdanku nebo Osvětimi v kremačních pecích (Hrabal 2012, s. 68).
Bohumil Hrabal bohaterami swojej prozy czynił osoby pochodzenia romskiego, ponieważ stanowiły dla niego interesujący kontrast z szarą rzeczywistością komunistycznej Czechosłowacji. Nie omieszkał opisać stereotypów upowszechnianych w społeczeństwie czeskim. Zarówno w Romancie, jak i Zbyt głośnej samotności starał się wpleść w fikcję literacką wątki autobiograficzne, wynikające z licznych spotkań i obserwacji praskich Romów. Stanowili oni dla niego uosobienie wolności, niezależności czy zewnętrznego piękna. Podjął próbę przybliżenia nie do końca rozumianej przez Czechów kultury romskiej z jej negatywnymi, jak i pozytywnymi aspektami. Otwarcie pisał o zagładzie Romów, ich tragedii, co w latach 60. i 70. XX wieku było aktem niezwykłej empatii.

\section{Literatura}

En g e 1 k ing L., 2015, Menzel i inni. Adaptacje filmowe prozy Bohumila Hrabala, „Konteksty Kultury” 12, nr 1.

F i c ow sk i J., 1953, Cyganie Polscy. Szkice historyczno-obyczajowe, Warszawa. H r a b a 1 B., 2012, Př́liš hlučná samota, Praha.

H r a b a 1 B., 2014, Spisy II. Skřivánek na niti. Povídky, Praha.

K a c z or o w s k i A., 2016, Hrabal. Stodka apokalipsa, Wołowiec.

L u b e c k a A., 2005, Tożsamość kulturowa Bergitka Roma, Kraków.

R o b e r t M., 2014, Peretki i skowronki. Adaptacje filmowe prozy Bohumila Hrabala, Łódź.

T a r a j 1 o - L i p o w s k a Z., 2010, Historia literatury czeskiej. Zarys, Wrocław.

W ę g r z y n G., 1992, Historyczno-społeczne uwarunkowania stereotypu Cygana, [w:] Amalgamat. O problemach kultury i społeczeństwa, red. M. Lubaś, Katowice.

W itkowsk i M., 2003, Romowie w Czechach. Podzialy i wspótdziałanie, [w:] Romowie o sobie $i$ dla siebie. Nowe problemy $i$ nowe działania $w$ pieciu krajach Europy Środkowo-Wschodniej, red. E. Nowicka, Warszawa. 